\title{
IDENTIFICAÇÃO DAS PERCEPÇÕES DE RESPONSABILIDADE SOCIAL EMPRESARIAL: UM ESTUDO QUALITATIVO A PARTIR DA APLICAÇÃ̃O DO MODELO CONCEITUAL TRIDIMENSIONAL DE PERFORMANCE SOCIAL
}

\author{
Nívea Marcela Marques Nascimento de Macêdo \\ Mestre em Engenharia de Produção pela Universidade Federal da Paraíba - UFPB \\ Pesquisadora do Grupo de Estudos em Gestão, Inovação e Tecnologia - GEGIT \\ niveamarcela@ig.com.br

\section{Gesinaldo Ataíde Cândido} \\ Doutorado em Engenharia de Produção pela Universidade Federal de Santa Catarina - UFSC \\ Professor da Universidade Federal de Campina Grande - UFCG \\ gesinaldo@pq.cnpq.br
}

\begin{abstract}
RESUMO
As empresas necessitam estar preparadas para os novos requisitos de atuação social, consolidados a partir das interferências dos atores sociais envolvidos com uma organização. Esses atores, os stakeholders, possuem relacionamentos distintos com o negócio e suas percepções em relação a atuação de uma empresa precisam ser consideradas. Assim, o objetivo desse estudo é identificar as percepções dos stakeholders acerca das ações de responsabilidade social adotadas por uma empresa têxtil do estado da Paraíba, utilizando o modelo tridimensional de performance social de Carroll (1979). Efetivou-se um estudo de caso e foram construídos roteiros de entrevista baseados no modelo em questão, sendo os dados analisados pela técnica de análise de conteúdo. Os resultados indicam que os agentes internos possuem uma opinião mais favorável em relação à empresa do que os agentes externos. Sendo a percepção dos agentes externos baseada em seu nível de conhecimento sobre o conceito de responsabilidade social e suas características intrínsecas, conclui-se que a empresa pesquisada necessita de iniciativas mais abrangentes que estimulem uma maior interação com seus stakeholders, que não possuem conhecimento suficiente da questões de responsabilidade social da empresa analisada.
\end{abstract}

Palavras-chave: Responsabilidade Social Empresarial; Gestão De Stakeholders; Empresa Têxtil.

\begin{abstract}
Before the current context of businesses, companies need to be prepared for the new requirements of social performance, consolidated from the social actors' interferences involved with an organization. Those actors, the stakeholders, possess different relationships with businesses and perceptions about a company's performance need to be considered regarding business efficiency. The objective of this study is to identify the stakeholders' perceptions about the actions of social responsibility adopted by a textile company of the state of Paraíba, using the three-dimensional model of social performance of Carroll (1979). A case study was executed and an interview approach was designed based on the model, the data were analyzed by the technique of content analysis. It was verified among the results that the internal agents possess a more favorable opinion to the company than the external agents. The perception of a company is based on one's knowledge level of the concept of social responsibility and intrinsic characteristics. It was concluded that the researched company needs to develop initiatives for a larger interaction with their stakeholders which do not possess enough knowledge on the concept of social responsibility as of their own characteristics.
\end{abstract}

Key words: Managerial Social Responsibility; Stakeholders Administration; Textile Company. 


\section{INTRODUÇÃO}

As empresas necessitam de estar preparadas para as novas formas de gestão, bem como aos novos requisitos de relevância e atuação social, consolidados a partir das necessidades e problemas dos atores sociais envolvidos com uma organização. Esses atores, os stakeholders, designam-se como os agentes com os quais uma organização mantém relacionamentos distintos necessários à sua sobrevivência. Esses relacionamentos precisam ser considerados, dada a importância que possuem para a empresa.

Nesse sentido, é necessário que as organizações criem relacionamentos sustentáveis com as partes interessadas (stakeholders), e para isso as empresas precisam se envolver socialmente, desenvolvendo um sentido de Responsabilidade Social Empresarial (RSE) coerente com a estratégia do negócio.

À medida que uma organização trabalha para estabelecer ações de RSE, ela está verificando os principais problemas, as opiniões e características de seus stakeholders, que estão atrelados a um conjunto de fatores culturais e administrativos de uma empresa. Assim, a RSE é um conceito diretamente relacionado à gestão de stakeholders, sendo possível verificar a ascensão, ao longo do tempo, dessas duas temáticas.

Atkinson, Waterhouse e Wells (1997) pontuam que a organização moderna é uma rede de contratos implícitos e explícitos que especificam a relação entre a empresa e seus stakeholders. Sendo assim, torna-se relevante considerar seus públicos de interesse.

Além disso, também é necessária uma abordagem que considere o entendimento e percepção desses stakeholders em relação à atuação social da empresa que estão relacionados, uma vez que essas percepções podem validar ou prejudicar tal atuação.

Carroll (1979) apresentou em seu modelo conceitual tridimensional de performance social a possibilidade de identificar as compreensões e entendimentos de pessoas envolvidas com uma organização. Sendo possível estabelecer sua percepção em relação a atuação social de uma empresa, salienta-se que cada setor ou atividade industrial possui stakeholders distintos, sendo a abordagem desse estudo feita com stakeholders de uma empresa do setor têxtil.

Assim, levando-se em conta que as necessidades e interferências dos stakeholders são integrantes da análise, construção e atuação social de uma empresa, como também interferem na sua estruturação, busca-se identificar as percepções dos diversos tipos de stakeholders acerca das ações de RSE adotadas por uma empresa do setor têxtil, utilizando o modelo conceitual tridimensional de performance social de Carroll (1979). Para isso, foi efetivada uma pesquisa exploratória, fundamentada na técnica de estudo de caso, em que foram selecionados alguns stakeholders da empresa em questão para a pesquisa por meio da amostragem não probabilística por acessibilidade.

Nesse sentido, deseja-se efetivar contribuições na área da RSE, uma vez que esse modelo possui pouca aplicabilidade na literatura. Almeja-se definir os parâmetros necessários para sua aplicabilidade, bem como as variáveis e os instrumentos de pesquisa específicos.

Além dessa introdução, esse estudo evidencia o conceito de RSE, discute sobre a teoria dos stakeholders e aborda o modelo conceitual tridimensional de Carroll (1979). Apresenta-se depois o suporte metodológico da pesquisa, os resultados encontrados no que se refere à percepção dos stakeholders pesquisados e as consequentes considerações finais.

\section{REFERENCIAL TEÓRICO}

\subsection{Conceituação da Responsabilidade Social}

A RSE é um processo em que as empresas integram, de forma voluntária, preocupações sociais e ambientais em suas operações e em sua interação com seus stakeholders. Essa atuação pode melhorar relações de parceria, o comprometimento com o trabalho, sendo um ponto de interação na procura de ações promissoras e eficazes, aperfeiçoando tanto a empresa quanto as relações que esta mantém com a sociedade. 
A RSE é um conjunto de ações que geram algum benefício, além dos interesses da firma e que são requeridas por lei. No entanto, em alguns casos, vai além dos requisitos exigidos pela lei, considerando-se, algumas vezes, as características relacionadas a valores e princípios individuais dos gestores, por pressões do mercado ou por possibilidades de retorno advindo do investimento social (Wartick, Cochran, 1985, Wood, 1991, McWilliams e Siegel, 2001). Ou seja, muitos podem ser os pontos norteadores para iniciativas sociais nas empresas. O que é evidenciado, a princípio, é que a RSE pressupõe que a representação dominante de globalização possui uma dimensão moral, tal qual suas dimensões políticas e econômicas. $\mathrm{O}$ conceito revela áreas nas quais o entendimento sobre o progresso deve ser revisto, deixando visível a necessidade de novas formas de diálogo sobre a interação entre empresas, governos e sociedades.

Na prática, toda teoria relativa à temática da RSE possui, em si, uma vinculação com as questões de geração de lucro, performance política, demandas sociais e valores éticos, mas abordam esses temas de forma diferenciada e com diferentes pesos (Garriga e Melé, 2004). Isso porque a forma como a empresa atua e desenvolve suas ações sociais está relacionada com sua cultura e estratégias específicas. De acordo com a natureza de suas atividades a ponderação da RSE pode diferir no cenário empresarial.

Dessa ponderação fazem parte características não só da empresa, mas de todo o conjunto de atores envolvidos. Em relação à participação dos atores envolvidos, Steurer, et al (2005) afirmam que a RSE é uma abordagem de gerenciamento voluntário, em que os stakeholders organizacionais têm uma função muito importante. Daí a necessidade do conhecimento de suas características e percepções, como também do nível de interferência (poder) que eles possuem de realizar práticas sociais na empresa.

Assim, abordagens que considerem as especificidades do conjunto de atores envolvidos com a organização são importantes e necessárias para a correta gestão e adoção da responsabilidade social por parte da organização.

\subsection{Teoria dos Stakeholders}

A teoria dos stakeholders mostra que os resultados das atividades organizacionais necessitam considerar o devido retorno aos grupos de indivíduos (stakeholders) envolvidos com a organização.

Para que a empresa obtenha eficiência e sobreviva aos concorrentes é importante que todos os atores sejam administrados nas suas necessidades e níveis de influência para com a organização. A premissa fundamental dessa teoria, segundo Wilson (2000), é que quanto mais fortes forem as relações de uma organização com seus parceiros externos e internos, mais fácil será para essa organização alcançar seus objetivos corporativos.

Defensores da teoria dos stakeholders, como Donaldson e Preston (1995), afirmam que há a necessidade, por parte dos administradores, de reconhecer os diferentes grupos envolvidos com a organização e seus interesses específicos. Nesse sentido, essa teoria constitui-se uma importante referência, uma vez que permite verificar a influência de cada um dos grupos envolvidos com a organização, entendendo como essa influência acontece.

A teoria está atrelada à responsabilidade social das empresas, dado o seu caráter moral de investigação e consideração das necessidades dos atores sociais e institucionais relacionados com uma organização.

O público almeja que as empresas desempenhem um papel que ultrapasse o fornecimento de bens e serviços e se torne atuante, beneficiando a comunidade, tratando os clientes como pessoas inteligentes e adotando um comportamento ético que suplante a legislação vigente. Assim, se a organização quer estar no mercado e deseja que seu produto tenha um diferencial, deve promover melhorias para a sociedade, atendendo, portanto, a necessidade dos stakeholders (Milano, Nunes, Kastrup, 2002). 
Para isso, é importante verificar, a princípio, quais são esses agentes relacionados, aqueles que fazem parte da "linha de frente" da firma e qual é a atuação desses agentes. Existem alguns autores que veem como stakeholders da empresa um leque restrito de atores, conforme a proposta de Friedman (1970); outros autores já incorporam um número maior de atores, como Clarkson (1995) e Donaldson e Preston (1995); e outros autores têm uma concepção larga dos atores envolvidos com a empresa, tais como o próprio Freeman (1999) e Carroll (1979, 1999).

Post et al (2002) asseveram que essa teoria é adequada para aumentar o valor da empresa. Em resumo, a riqueza de uma organização está baseada na qualidade de suas relações com seus stakeholders. Observa-se assim a intrínseca relação entre RSE e teoria dos Stakeholders, uma vez que, para a correta atividade de atuação social, é necessária a consideração, pela empresa, do papel e importância de todos os atores que mantém uma interação e são por ela influenciados.

Existem muitos modelos que procuram reformular e aprimorar o conceito de RSE e a consequente consideração dos stakeholders, objetivando desenvolver um entendimento mais claro sobre o tema e os aspectos relacionados. Destacam-se estudos relevantes, no âmbito nacional e internacional, como os de Wartick e Cochran (1985), Wood (1991), Enderle e Tavis (1998) e Quazi e O'brien (2000). Todas essas abordagens são derivadas de um único estudo em particular, o de Carroll (1979), denominado modelo conceitual tridimensional de performance social, que será explanado a seguir.

\subsection{Modelo Conceitual Tridimensional de Performance Social}

O modelo tridimensional de performance social foi proposto por Archie B. Carroll em 1979, com vistas a integrar conceitos e promover uma análise multidimensional da RSE. O autor considera três dimensões distintas no trato da RSE. A primeira trata da obrigação da responsabilidade social, que são as categorias econômica, legal, ética e discricionária. A segunda diz respeito a toda uma gama de ações ou programas sociais que a empresa pode focar ou priorizar. A terceira dimensão trata-se do tipo de resposta que a empresa pode apresentar ante sua postura de relevância social. A Figura 1 mostra o cubo que explana as três dimensões em questão.

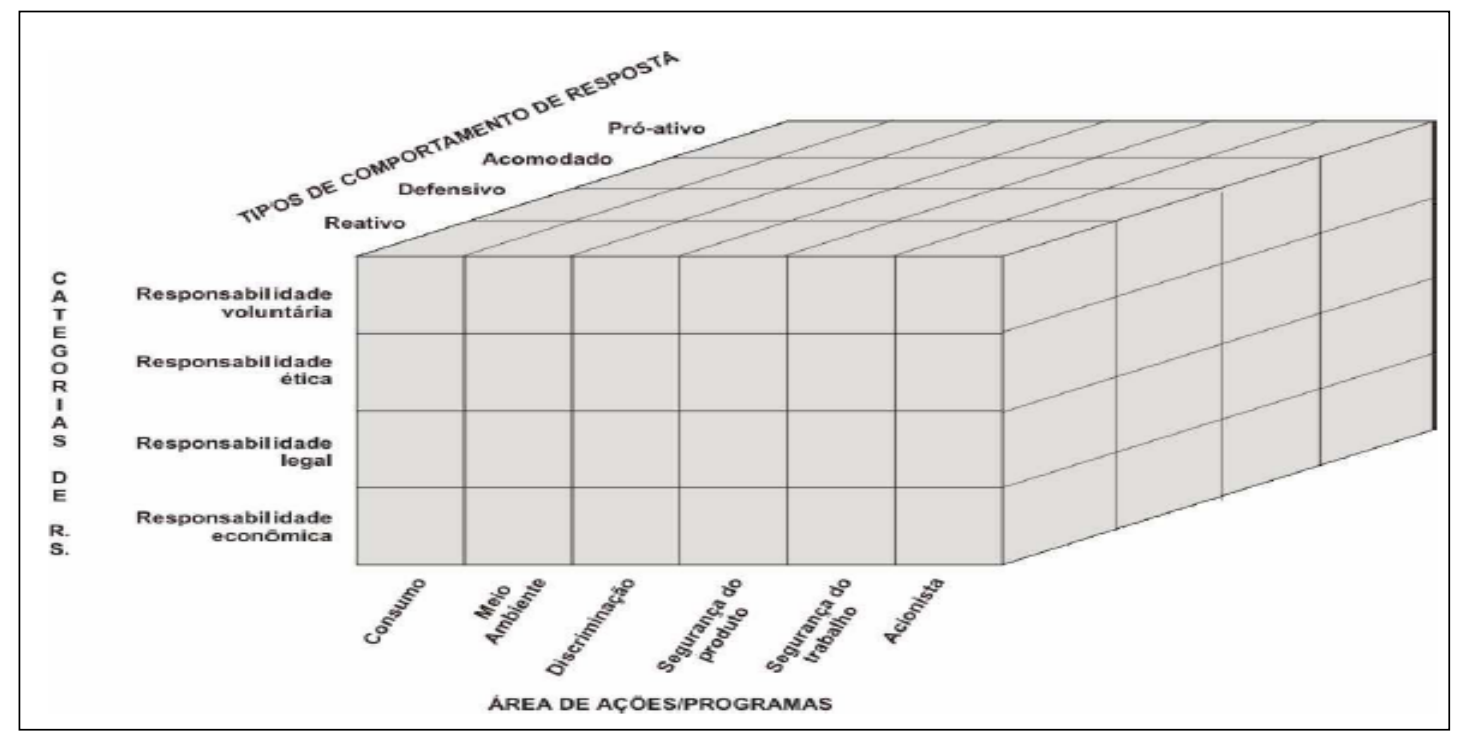

Figura 1: Modelo Tridimensional de Performance Social Corporativa Fonte: Carroll (1979, p. 503)

Esses três ângulos de análise forçam a consideração das principais questões que devem ser analisadas na performance social de uma empresa (Carroll, 1979). Para Welzel et al, (2008) o modelo de RSE idealizado por Carroll (1979) é tido como explicativo fundamental do tema. 
A primeira dimensão diz respeito às categorias de RSE relacionadas às responsabilidades ou obrigações do negócio. Nela tem-se a responsabilidade econômica, em que a empresa tem a necessidade de oferecer ao seu público produtos e serviços adequados, além de garantir o retorno financeiro aos acionistas, sócios, fornecedores, funcionários e parceiros. A responsabilidade legal determina que as leis e regulamentações formam a estrutura legal sobre a qual se espera que os negócios operem. A responsabilidade ética, considerada como a mais difícil de ser trabalhada e praticada nos negócios, implica na análise e reflexão ética na tomada de decisões na empresa. E a responsabilidade discricionária aborda os atos voluntários e que ficam por conta do julgamento individual dos gestores da organização.

É válido considerar que para entender a complexidade da RSE nas organizações modernas é necessário incorporar uma visão mais vasta da sociedade, considerando o macro ambiente, suas necessidades e anseios, conforme explanam Carroll (1979) e Wood (1991). Nesse sentido, a estrutura desse modelo aborda outra dimensão que consiste nas ações e programas sociais que podem ser foco de atuação social de uma organização.

Carroll (1979) aponta que essas ações e programas são diferentes para cada indústria e sua consideração e relevância dependem do contexto e dos stakeholders envolvidos com a firma; podem estar ligadas à natureza de seus produtos ou relacionadas à sua cultura. Essas áreas são descritas no modelo como a ênfase na segurança do produto, do processo ou do trabalho, meio ambiente, consumo e acionistas. Entretanto, o autor expõe que não necessariamente a empresa pode ter um desses focos no trabalho com questões sociais, ficando a cargo do pesquisador/gestor identificar quais as áreas ou recursos uma empresa prioriza em suas ações socialmente responsáveis.

A forma de comportamento e resposta do gestor designa-se como a terceira dimensão do modelo de Carroll (1979). Para o autor, o termo geralmente usado para descrever esse aspecto é chamado de resposta ou responsividade social. Apresentam-se, a seguir, os tipos de respostas propostas no modelo:

a) Reativa: a empresa responde a uma questão social depois que ela ameaça seus objetivos, ou seja, depois que algum problema interfere em seu efetivo funcionamento;

b) Defensiva: a empresa age para se proteger ou se defender de um desafio ou problema;

c) Acomodativa: a empresa se alinha às exigências do governo ou da opinião pública;

d) Proativa: a empresa antecipa exigências que ainda não foram feitas.

Como pontua o autor, enfoques, antes tidos em separado, como as formas de resposta social, categorias e focos de análise da empresa, foram expostos em conjunto, conforme três dimensões de uma mesma abordagem. O modelo foi sugerido para ser utilizado principalmente na área acadêmica, como uma base conceitual, no entanto pode ser considerado um mecanismo para apreciação do entendimento dos stakeholders sobre determinadas questões ou atuação social de dada organização, se preenchidas as lacunas existentes. O modelo tridimensional de performance social representa uma das grandes contribuições dadas à área de RSE. Muitos autores, posteriormente, o mencionaram e desenvolveram estudos com base em Carroll (1979).

Nesse sentido, observando a importância que possui o referido modelo na literatura relacionada, destaca-se a relevância de estruturar uma aplicação ou estudo empírico, com base nas conceituações de Carroll (1979), se preenchidas as devidas lacunas existentes.

Com isso, apresenta-se o suporte metodológico que tornou possível a inédita aplicação do referido modelo mediante o objetivo estabelecido para essa pesquisa.

\section{PROCEDIMENTOS METODOLÓGICOS}

Esse estudo caracteriza-se como exploratório, uma vez que pretendeu considerar o conceito de RSE e suas características em um contexto específico. Uma pesquisa descritiva também foi necessária para a caracterização da empresa e suas relações com os envolvidos. Para análise da

Revista de Gestão Social e Ambiental - RGSA, São Paulo, v.5, n.1, p. 85-108, jan./abr., 2011. 
percepção dos stakeholders, construíram-se roteiros de entrevista semiestruturados com base no modelo conceitual tridimensional. Para interpretação das falas dos entrevistados, utilizou-se a técnica da análise de conteúdo temática. Essa técnica permite reduzir e reorientar muitas palavras de um texto, que se constituem nesse estudo nas entrevistas realizadas em categorias de conteúdo que têm como parâmetro as normas de codificação. Nesse sentido, investigou-se as falas representativas da definição de cada variável do modelo em questão.

Quanto aos meios, utilizou-se o estudo de caso. Esse tipo de estudo permite uma análise mais profunda da organização, proporcionando um maior conhecimento do objeto de pesquisa por sua flexibilidade. Yin (1984, p.14) afirma que uma investigação caracteriza-se como um estudo de caso se "surge o desejo de compreender fenômenos sociais complexos".

Essa pesquisa foi realizada em uma empresa do setor têxtil situada no estado da Paraíba, que fabrica fios e tecidos naturais. Pela solicitação do anonimato, não foi possível relacionar outras de suas características e envolvidos e, por isso, adotará o nome Têxtil, e seu principal projeto educacional desenvolvido será chamado apenas de projeto educacional. Ao todo possui 1.580 funcionários e está há 15 anos no mercado. Suas primeiras iniciativas sociais ocorreram há cerca de 10 anos. Entre alguns projetos em parceria destacam-se inclusão digital, música, culinária, academia, tratamento para viciados em drogas, esporte, indústria do conhecimento. Entre os projetos próprios, destacam-se auxílios planos de saúde, supermercado, farmácia, atividades desportivas, convênio livraria e doações à comunidade.

O público-alvo das ações sociais envolve, principalmente, os funcionários e alguns indivíduos da comunidade. Essa empresa é a principal responsável pela distribuição e comércio de fios e tecidos brutos da região, sendo assim importante para esse tipo de comércio local e regional.

Conforme especificado, foram criadas variáveis para dar suporte à construção dos instrumentos de pesquisa, que serão explicitadas a seguir:

\subsection{Variáveis da Pesquisa}

Para uma adequada aplicabilidade do modelo tridimensional de performance social, foram criadas variáveis que podem ser identificadas em cada dimensão do cubo tridimensional de Carroll (1979). Sendo a construção/criação e possível validação de variáveis de cada uma das dimensões do modelo uma das principais contribuições desse estudo.

Explicita-se que algumas variáveis foram contempladas na pesquisa com stakeholders internos e outras com stakeholders externos, uma vez que cada grupo e natureza de stakeholder está apto a responder por determinada área e abrangência (um consumidor não possui as mesmas informações sobre atuação social que um gerente ou cliente e assim sucessivamente) e, por isso, a construção de variáveis e instrumentos de pesquisa específicos. Assim, três roteiros foram feitos: um para gerentes, outro para funcionários e um terceiro para atores externos à organização. Esse fator foi diretamente identificado por intermédio de pré-testes de pesquisa realizados com algumas pessoas da empresa em questão.

Para cada uma das três dimensões, procurou-se diagnosticar as variáveis relacionadas. A primeira dimensão consiste nas categorias de desempenho social que a empresa pode apresentar. O Quadro1 mostra as dimensões do modelo e suas variáveis criadas:

\begin{tabular}{|l|c|}
\hline \multirow{4}{*}{ CATEGORIAS } & MODELO TRIDIMENSIONAL DE PERFORMANCES SOCIAIS \\
\hline \multirow{4}{*}{ Econômica } & VARIÁVEIS \\
\hline & Equilíbrio entre receitas e despesas \\
\cline { 2 - 3 } & Satisfação de clientes como indicador de desempenho do negócio \\
\cline { 2 - 3 } & Transações satisfatórias para stakeholders \\
\cline { 2 - 3 } & Monitoramento da produtividade dos funcionários \\
\cline { 2 - 3 } & Preços convenientes ao poder de compra da demanda \\
\cline { 2 - 3 } & Investimento em estrutura física, treinamento dos funcionários e novos produtos \\
\cline { 2 - 2 } & Produção de bens e provisão de serviços de acordo com os requisitos da demanda \\
\hline
\end{tabular}




\begin{tabular}{|c|c|}
\hline \multirow{4}{*}{ Legal } & Efetividade no pagamento de impostos e tributos municipal, estadual e federal \\
\hline & Cumprimento integral das leis do trabalho e obrigações contratuais \\
\hline & Adequação dos produtos ao Código de Defesa do Consumidor \\
\hline & Cumprimento de normas técnicas e de legislação ambiental \\
\hline \multirow{4}{*}{ Ética } & Existência e aplicação de um código de ética na empresa \\
\hline & Respeito à integridade física e moral de funcionários e clientes \\
\hline & $\begin{array}{c}\text { Abertura ou procedimento confidencial na empresa para funcionários tratarem questões } \\
\text { problemáticas }\end{array}$ \\
\hline & Fomento de uma cultura interna para criação e adoção de valores éticos \\
\hline \multirow{4}{*}{ Discricionária } & Desenvolvimento de iniciativas sociais em benefício da comunidade local \\
\hline & Estímulo ao voluntariado nos clientes internos \\
\hline & $\begin{array}{c}\text { Participação em organizações cívicas ou consideração de problemas sociais da } \\
\text { comunidade }\end{array}$ \\
\hline & Disponibilidade aos funcionários para aquisição de habilitações suplementares \\
\hline
\end{tabular}

Quadro 1: Variáveis da dimensão Categorias do modelo de Carroll (1979)

Fonte: Elaboração Própria com base em Carroll (1979)

A segunda dimensão refere-se aos comportamentos de resposta que uma organização pode apresentar quanto à sua performance social. A Quadro 2 apresenta as variáveis criadas para cada resposta.

\begin{tabular}{|c|c|}
\hline \multicolumn{2}{|c|}{ MODELO TRIDIMENSIONAL DE PERFORMANCES SOCIAIS } \\
\hline RESPOSTAS & VARIÁVEIS \\
\hline \multirow[b]{2}{*}{ Reativo } & Fomento de ações sociais depois de protesto ou reivindicações da sociedade \\
\hline & $\begin{array}{l}\text { Ações sociais para viabilizar a mitigação de impactos negativos provocados } \\
\text { pela empresa }\end{array}$ \\
\hline \multirow{4}{*}{ Defensivo } & Realização de auditorias freqüentes \\
\hline & $\begin{array}{c}\text { Revisão periódica das ações sociais para conformidade com objetivos } \\
\text { empresariais }\end{array}$ \\
\hline & Desenvolvimento de ações ou programas sociais no intuito de evitar problemas \\
\hline & Receptividade para relevância de problemas sociais ocasionados pela empresa \\
\hline \multirow{3}{*}{ Acomodativo } & $\begin{array}{l}\text { Gestão administrativa de acordo com as expectativas/necessidades dos } \\
\text { funcionários }\end{array}$ \\
\hline & Projetos sociais para cumprir às normas e legislação governamental \\
\hline & Atuação social tendo em vista o que a empresa necessita e o governo solicita \\
\hline \multirow{4}{*}{ Pró-ativo } & $\begin{array}{l}\text { Institucionalização de projetos educacionais, culturais, éticos, internamente ou } \\
\text { na comunidade }\end{array}$ \\
\hline & Atuação social como forma de antecipar-se aos problemas \\
\hline & Desempenho de projetos por iniciativa própria \\
\hline & Existência de relação entre planejamento empresarial e estratégias sociais \\
\hline
\end{tabular}

Quadro 2: Variáveis da dimensão Comportamentos de Respostas do modelo de Carroll (1979)

Fonte: Elaboração Própria com base em Carroll (1979)

A terceira dimensão do modelo consiste nas ações e programas que podem ser foco de atuação social de uma organização. O Quadro 3 apresenta as variáveis criadas.

\begin{tabular}{|c|c|}
\hline \multicolumn{2}{|r|}{ MODELO TRIDIMENSIONAL DE PERFORMANCES SOCIAIS } \\
\hline AÇÕES & VARIÁVEIS \\
\hline \multirow{4}{*}{ Consumo } & $\begin{array}{l}\text { Modificação e/ou retirada de produtos após sua distribuição quando não adequados à } \\
\text { clientes ou consumidores }\end{array}$ \\
\hline & Disposição de informações técnicas adequadas e necessárias \\
\hline & Realização de pesquisas de mercado \\
\hline & Relacionamento pós-venda satisfatório com o cliente \\
\hline Meio Ambiente & $\begin{array}{c}\text { Disposição de informações sobre educação ou consciência ambiental no âmbito } \\
\text { externo }\end{array}$ \\
\hline
\end{tabular}

Revista de Gestão Social e Ambiental - RGSA, São Paulo, v.5, n.1, p. 85-108, jan./abr., 2011. 


\begin{tabular}{|c|c|}
\hline & Enquadramento da empresa com certificação ambiental \\
\hline & Tratamento e reutilização de água proveniente da produção \\
\hline & Disposição adequada de resíduos sólidos e gases poluentes \\
\hline & Utilização de tecnologias limpas ou que reduziram a poluição \\
\hline & Desenvolvimento de projetos voltados à preservação do meio ambiente \\
\hline \multirow{5}{*}{ Discriminação } & Igualdade de condições salariais, independentemente de sexo \\
\hline & Igualdade na ocupação de cargos de chefia a pessoas de qualquer raça ou sexo \\
\hline & Liberdade de escolha e prática religiosa \\
\hline & $\begin{array}{l}\text { Segurança para o emprego ou contratação de funcionários com mais de } 45 \text { anos de } \\
\text { idade }\end{array}$ \\
\hline & $\begin{array}{c}\text { Trabalho para mitigação de discriminação social ou racial entre funcionários ou outros } \\
\text { relacionados à empresa }\end{array}$ \\
\hline \multirow{5}{*}{ Segurança do produto } & Disponibilidade de informações sobre normas técnicas necessárias à correta fabricação \\
\hline & \begin{tabular}{|c|} 
Implantação de meios que busquem a excelência do padrão de qualidade \\
\end{tabular} \\
\hline & Execução de medidas eficazes de logística \\
\hline & Ambiente sanitariamente adequado para produção e estoque \\
\hline & Produtos seguros à saúde de consumidores \\
\hline \multirow{4}{*}{ Segurança do Trabalho } & Fiscalização e monitoramento da utilização de equipamentos de proteção \\
\hline & Treinamentos para manejo adequado de ferramentas e máquinas \\
\hline & Fiscalização de infraestrutura para impedir danos à saúde dos funcionários \\
\hline & Diminuição do índice de acidentes nas operações do trabalho \\
\hline \multirow{4}{*}{ Acionistas } & Contínua prestação de contas aos acionistas da empresa \\
\hline & $\begin{array}{l}\text { Mediação de interesses dos sócios acionistas com os objetivos de comprometimento } \\
\text { social }\end{array}$ \\
\hline & $\begin{array}{c}\text { Elaboração de programa de envolvimento de acionistas com projetos sociais da } \\
\text { empresa }\end{array}$ \\
\hline & $\begin{array}{c}\begin{array}{c}\text { Estudo em conjunto com acionistas sobre as implicações da atuação social responsável } \\
\text { na competitividade e no aumento de lucratividade }\end{array} \\
\end{array}$ \\
\hline
\end{tabular}

As entrevistas foram presenciais e transcritas no momento em cada respondente expressavase. Pontua-se que os respondentes ficaram livres para responder como quisessem, e que algumas de suas respostas abriam a possibilidade para questionamentos aquém do roteiro estabelecido.

Seria necessário considerar para pesquisa atores sociais envolvidos e que conhecessem as ações realizadas, para que fosse possível avaliar seu entendimento - percepção - em relação a essas ações. Com isso, optou-se por utilizar a amostragem não probabilística por acessibilidade, que seleciona elementos pela facilidade de acesso e que sejam representativos da população-alvo a ser pesquisada. A partir disso, a pesquisa deu-se com um diretor (o principal responsável pelo planejamento e manutenção das atividades sociais da empresa), 5 funcionários (3 voluntários e 2 não voluntários dos projetos sociais), 3 fornecedores, 2 clientes, 3 representantes de um parceiro, 3 consumidores e 4 da comunidade. Não foi possível realizar a pesquisa com acionistas pelo fato de eles não se encontrarem diretamente ligados com a filial em questão e por não conhecerem suas características mais particulares.

Ressalta-se que um recurso também utilizado para diagnóstico das percepções foi a observação não participante, e essa propiciou uma análise mais abrangente, visto que foi possível confirmar ou não os dados primários levantados, bem como fazer maior observação dos relacionamentos da empresa.

\section{RESULTADOS DA PESQUISA}

A seguir, apresentam-se os resultados para cada grupo de stakeholder pesquisado em particular. Destaca-se que não é possível abordar a percepção dos entrevistados sobre todas as variáveis criadas para as três dimensões do modelo, por isso buscou-se expor as opiniões mais 
características de algumas variáveis que resumem, de modo direto, a percepção sobre cada dimensão do modelo tridimensional.

\subsection{Percepção dos Funcionários}

Procurou-se verificar perspectivas e entendimentos de funcionários situados em setores distintos, para obter informações diversificadas. Entre os respondentes três do setor administrativo, um da biblioteca e um do setor de informática.

A partir do Quadro 4 é possível observar as opiniões dos funcionários entrevistados sobre algumas variáveis da dimensão Categorias de responsabilidade social.

\begin{tabular}{|c|c|c|}
\hline CATEGORIAS & VARIÁVEL & PERCEPÇÃO \\
\hline Econômica & $\begin{array}{l}\text { Investimento em estrutura } \\
\text { física, treinamento dos } \\
\text { funcionários e novos produtos }\end{array}$ & $\begin{array}{l}\text { "Os produtos são de qualidade e acredito que os } \\
\text { investimentos feitos são satisfatórios". }\end{array}$ \\
\hline \multirow{3}{*}{ Legal } & $\begin{array}{l}\text { Cumprimento integral das leis } \\
\text { do trabalho e obrigações } \\
\text { contratuais }\end{array}$ & $\begin{array}{c}\text { "Acho que a empresa faz pelos colaboradores o que } \\
\text { tem que fazer. Toda empresa tem que oferecer boas } \\
\text { condições de trabalho, acho que é mais ou menos o } \\
\text { que é feito". }\end{array}$ \\
\hline & $\begin{array}{l}\text { Cumprimento de normas } \\
\text { técnicas e de legislação } \\
\text { ambiental }\end{array}$ & $\begin{array}{l}\text { “[...] É tudo de acordo com a legislação ambiental. } \\
\text { Até pela natureza dos produtos que são fabricados". }\end{array}$ \\
\hline & $\begin{array}{l}\text { Adequação dos produtos ao } \\
\text { Código de Defesa do } \\
\text { Consumidor }\end{array}$ & "O código de defesa do consumidor é atendido". \\
\hline Ética & $\begin{array}{l}\text { Procedimento confidencial na } \\
\text { empresa para funcionários } \\
\text { tratarem questões } \\
\text { problemáticas }\end{array}$ & $\begin{array}{l}\text { "Não existe esse procedimento. Mas a gente tem } \\
\text { alguma abertura pra falar de algum problema. } \\
\text { Também quando vamos trabalhando estamos vendo } \\
\text { como se comportar, mas, com certeza, se tivesse } \\
\text { uma maneira pra se comunicar sobre problemas } \\
\text { seria melhor". }\end{array}$ \\
\hline \multirow[b]{2}{*}{ Discricionária } & $\begin{array}{l}\text { Desenvolvimento de iniciativas } \\
\text { sociais em benefício da } \\
\text { comunidade local }\end{array}$ & $\begin{array}{l}\text { "Sim. Existe um grande projeto que é em benefício } \\
\text { da comunidade, para a educação de jovens e } \\
\text { adolescentes. Mas a maioria dos projetos feito aqui } \\
\text { busca beneficiar os colaboradores". }\end{array}$ \\
\hline & $\begin{array}{l}\text { Participação em organizações } \\
\text { cívicas ou consideração de } \\
\text { problemas sociais da } \\
\text { comunidade }\end{array}$ & $\begin{array}{c}\text { “Tem muitas campanhas, mas a principal é o nosso } \\
\text { maior projeto educacional, porque é inteiramente } \\
\text { para o público externo. A empresa não tem tanta } \\
\text { abertura com a comunidade porque não existe clima } \\
\text { pra isso. [...]”. }\end{array}$ \\
\hline
\end{tabular}

Quadro 4: Resultados da dimensão Categorias - Funcionários Gerais

Fonte: Elaboração própria a partir dos dados da pesquisa.

Pelas opiniões apresentadas é possível verificar que as categorias são bem avaliadas pelos funcionários entrevistados, sendo a maior concordância vinda da categoria legal. Isso porque os funcionários reconhecem que os projetos são feitos pela própria necessidade da empresa de estar em conformidade com leis e regulamentos, embora tenha sido possível verificar que outras pessoas, principalmente voluntários, entendem que a Têxtil realiza ações que estão além da sua obrigação, tais como as visitas familiares e as doações realizadas. A categoria ética não foi evidenciada, dada a não existência de procedimento para reclamações e de código de ética. Na categoria discricionária, observa-se que não há tanta interação entre empresa e comunidade e que essa ausência se deve, principalmente, à falta de esclarecimento sobre os benefícios desse tipo de relação. Como também os principais projetos sociais são feitos em benefício dos clientes internos, e desenvolvidos em parceria, não sendo possível afirmar que sua iniciativa e recursos partem inteiramente da empresa. 
Identificação das percepções de responsabilidade social empresarial: um estudo qualitativo a partir da aplicação do modelo conceitual tridimensional de performance social

No que concerne à dimensão comportamentos e respostas de RSE, o Quadro 5 apresenta os principais resultados.

\begin{tabular}{|c|c|c|}
\hline $\begin{array}{l}\text { COMPORTAMENTOS DE } \\
\text { RESPOSTAS }\end{array}$ & VARIÁVEIS & PERCEPÇÕES \\
\hline \multirow{2}{*}{ Reativa } & $\begin{array}{l}\text { Fomento de ações } \\
\text { sociais depois de } \\
\text { protesto ou } \\
\text { reivindicações da } \\
\text { sociedade }\end{array}$ & $\begin{array}{c}\text { "Como te falei, a sociedade não tem iniciativa de procurar } \\
\text { ações ou de requerer algo da empresa. As ações são mais } \\
\text { pra melhorar o ambiente, pra fazer o que precisa ser feito. } \\
\text { As pessoas de fora não conhecem os projetos e vejo que } \\
\text { nem buscam procurar saber." }\end{array}$ \\
\hline & $\begin{array}{l}\text { Ações sociais para } \\
\text { viabilizar a mitigação } \\
\text { de impactos } \\
\text { negativos provocados } \\
\text { pela empresa } \\
\end{array}$ & $\begin{array}{c}\text { "Não. A empresa não enfrenta problemas. A sociedade não } \\
\text { reclama, pois ela não interfere ou tem (sofre) interferência } \\
\text { dos projetos. A não ser o nosso projeto educacional, mas é } \\
\text { mais aqui na comunidade local". }\end{array}$ \\
\hline \multirow{2}{*}{ Acomodativa } & $\begin{array}{l}\text { Gestão } \\
\text { administrativa em } \\
\text { acordo com as } \\
\text { expectativas/necessid } \\
\text { ade dos funcionários }\end{array}$ & $\begin{array}{l}\text { "Existem benefícios como convênio saúde, cesta básica, } \\
\text { transporte e outros. [...] Os colaboradores não se } \\
\text { interessam em interagir mais fortemente com a empresa na } \\
\text { busca do desempenho de um trabalho melhor". }\end{array}$ \\
\hline & $\begin{array}{l}\text { Projetos sociais para } \\
\text { cumprir às normas e } \\
\text { legislação } \\
\text { governamental }\end{array}$ & $\begin{array}{l}\text { "As exigências legais são cumpridas, e existem algumas } \\
\text { iniciativas que estão além disso, como as parcerias para os } \\
\text { projetos de educação e aperfeiçoamento profissional para } \\
\text { os colaboradores. Mas não são todos os projetos que são } \\
\text { feitos por envolvimento próprio". }\end{array}$ \\
\hline Pró-Ativa & $\begin{array}{l}\text { Desenvolvimento de } \\
\text { projetos por } \\
\text { iniciativa própria } \\
\end{array}$ & $\begin{array}{l}\text { "A grande maioria dos projetos não é por iniciativa } \\
\text { própria, sempre tem parceria". }\end{array}$ \\
\hline
\end{tabular}

Quadro 5: Resultados da dimensão Comportamentos de respostas - funcionários

Fonte: Elaboração própria a partir dos dados da pesquisa

Verificou-se que o comportamento reativo não foi visto como característica da Têxtil pelos funcionários. Uma vez que a comunidade não possui uma prática de interação com a empresa, não é possível manifestar com maior intensidade, apesar de não ser impossível, uma reivindicação ou princípio de protesto. O comportamento defensivo também não foi visto pelos funcionários como tipo de resposta, uma vez que as atividades relacionadas à esporte, produção de conhecimento, culinária, tratamento com drogas e inclusão de deficientes não foram motivadas, segundo observação, pelo surgimento de conflitos, falta de integração ou atividades insuficientes no trabalho.

Já a resposta acomodativa foi mais pontuada pelos funcionários. Para eles, as ações desenvolvidas estão de acordo com suas expectativas, até porque pelo que se observa as expectativas não são muitas. No entanto, não é possível afirmar que essas mesmas ações possuem um caráter abrangente, pondo a empresa em posição de se antever e fomentar projetos antes que problemas aconteçam.

A terceira dimensão diz respeito às ações e programas foco de atuação social da empresa. Quadro 6 apresenta os resultados que melhor explanam a percepção dos investigados.

\begin{tabular}{|c|c|c|}
\hline $\begin{array}{c}\text { AÇÕES E } \\
\text { PROGRAMAS }\end{array}$ & VARIÁVEIS & PERCEPÇÃO \\
\hline MEIO AMBIENTE & $\begin{array}{l}\text { Disposição adequada de resíduos } \\
\text { sólidos e gases poluentes }\end{array}$ & $\begin{array}{l}\text { "[...] Os resíduos gerados são quase que totalmente } \\
\text { biológicos; até a goma usada para engomar o fio } \\
\text { não agride nada. Tem uma lagoa para estabilização } \\
\text { onde as bactérias absorvem os restos da fabricação } \\
\text { do fio e tecido. O processo de produção também não } \\
\text { emite gases tóxicos." }\end{array}$ \\
\hline
\end{tabular}




\begin{tabular}{|c|c|c|}
\hline & $\begin{array}{l}\text { Desenvolvimento de projetos voltados } \\
\text { à preservação do meio ambiente }\end{array}$ & $\begin{array}{c}\text { "O processo de produção não agride o meio } \\
\text { ambiente. Mas não existem projetos para } \\
\text { preservação de espécies ou outros". }\end{array}$ \\
\hline \multirow[t]{2}{*}{ DISCRIMINAÇÃO } & $\begin{array}{l}\text { Igualdade na ocupação de cargos de } \\
\text { chefia a pessoas de qualquer raça ou } \\
\text { sexo } \\
\end{array}$ & $\begin{array}{l}\text { "Os cargos de chefia são ocupados independente da } \\
\text { raça ou sexo e os benefícios também são } \\
\text { distribuídos igualitariamente". }\end{array}$ \\
\hline & $\begin{array}{l}\text { Igualdade de condições salariais, } \\
\text { independentemente do sexo }\end{array}$ & $\begin{array}{c}\text { "[...] a questão da igualdade de salários eu acho que } \\
\text { é algo que ainda precisa melhorar." }\end{array}$ \\
\hline \multirow[b]{2}{*}{$\begin{array}{l}\text { SEGURANÇA DO } \\
\text { TRABALHO }\end{array}$} & $\begin{array}{l}\text { Fiscalização e monitoramento da } \\
\text { utilização de equipamentos de proteção }\end{array}$ & $\begin{array}{l}\text { "Os EPIs são fiscalizados e têm treinamento pra sua } \\
\text { utilização". }\end{array}$ \\
\hline & $\begin{array}{l}\text { Diminuição do índice de acidentes nas } \\
\text { operações do trabalho }\end{array}$ & $\begin{array}{l}\text { "Acidentes acontecem, mas nem sempre é culpa da } \\
\text { empresa. O número de treinamentos foi } \\
\text { intensificado de um ano e meio pra cá e a } \\
\text { quantidade de acidentes caiu muito depois disso." }\end{array}$ \\
\hline
\end{tabular}

Quadro 6: Resultados da dimensão Ações e Programas - Funcionários gerais Fonte: Elaboração própria a partir dos dados da pesquisa.

Em relação à ação e programa consumo, destaca-se que todas as variáveis foram vistas como existentes, ressalvando-se apenas que, dada a natureza dos produtos, não são necessárias pesquisas frequentes de mercado. No que concerne à ação meio ambiente, foi observada a intenção para obtenção de certificação ambiental, Sistema de Gestão ISO 14001 ou selo verde. E fica claro para os funcionários também que os resíduos são reutilizados.

Em relação ao foco discriminação, os funcionários não verificaram aplicabilidade. $\mathrm{Na}$ verdade, ela é vista como uma questão problemática na empresa. Reforça-se que as ações adotadas poderiam ser melhor construídas na Têxtil, caso a questão da discriminação fosse mais considerada.

As respostas às variáveis da segurança do produto foram positivas, no entanto, a empresa não possui certificação nessa área, o que inviabiliza para os funcionários um foco de atuação nesse sentido. Na segurança do trabalho, para os pesquisados, a Têxtil enfrenta alguns problemas. No entanto, as opiniões mostram que as principais questões conflitantes estiveram maiores nos últimos dois anos, e que atitudes foram tomadas para sanar a falta de treinamentos e o número de acidentes no trabalho.

Pela identificação das percepções dos funcionários acerca das ações e programas, fica evidenciado que nenhum dos componentes dessa dimensão é visto por eles como característico da empresa. Eles verificam que o foco das ações sociais da Têxtil é a manutenção de um ambiente favorável à eficiente realização das atividades diárias; e de fato existe esse foco. É válido observar que Carroll (1979) evidencia que essa dimensão é passível à introdução de ações e programas além e igualmente importantes ao modelo. Assim, segundo os pesquisados, a Têxtil possui uma responsabilidade legal, com o tipo de resposta acomodativa e foco de atuação social nos funcionários. Este último, tendo sido inserido como ação ou programa no cubo tridimensional da empresa.

Observou-se que as interpretações e percepções dos funcionários podem ser consideradas diferentes, dependendo da atividade desempenhada na empresa. De fato, o entendimento sobre responsabilidade social ainda não faz parte do cotidiano da organização, nem os funcionários se apropriaram dele para tal.

\subsection{Percepção do Diretor} pesquisadas:

O Quadro 7 apresenta as percepções do diretor entrevistado sobre algumas variáveis

\begin{tabular}{|c|c|c|}
\hline CATEGORIAS & VARIÁVEIS & PERCEPÇ̃̃O \\
\hline LEGAL & Efetividade no & "Nesse sentido há total regularidade. Os impostos são devidamente \\
\hline
\end{tabular}

Revista de Gestão Social e Ambiental - RGSA, São Paulo, v.5, n.1, p. 85-108, jan./abr., 2011. 


\begin{tabular}{|c|c|c|}
\hline & $\begin{array}{l}\text { pagamento de } \\
\text { impostos e tributos } \\
\text { municipal, estadual e } \\
\text { federal/Cumprimento } \\
\text { integral das leis do } \\
\text { trabalho e obrigações } \\
\quad \text { contratuais } \\
\end{array}$ & $\begin{array}{c}\text { pagos e os benefícios a empresa adota todos. [...] Agente procura } \\
\text { fazer como um plano de ações, que vão desde nossas necessidades } \\
\text { legais, mas também procuramos desenvolver o que pode trazer mais } \\
\text { satisfação aos funcionários, e isso se envolve também projetos } \\
\text { voluntários". }\end{array}$ \\
\hline DISCRICIONÁRIA & $\begin{array}{l}\text { Desenvolvimento de } \\
\text { iniciativas sociais em } \\
\text { benefício da } \\
\text { comunidade local }\end{array}$ & $\begin{array}{l}\text { “Nosso projeto educacional para jovens e adolescentes é um } \\
\text { exemplo de projetos para a comunidade. Mas a maioria de nossos } \\
\text { projetos visa proporcionar um melhor ambiente de trabalho pra os } \\
\text { colaboradores, são principalmente em benefício deles. [...] A } \\
\text { interação com pessoas de fora não é grande. Porque nunca tomamos } \\
\text { a iniciativa de organizar os dados e fazer um balanço social". }\end{array}$ \\
\hline RESPOSTAS & VARIÁVEIS & PERCEPÇÃO \\
\hline ACOMODATIVA & $\begin{array}{l}\text { Atuação social, tendo } \\
\text { em vista o que a } \\
\text { empresa necessita e o } \\
\text { governo solicita }\end{array}$ & $\begin{array}{l}\text { "Temos alguns projetos próprios e muitos em parceria, e eles estão } \\
\text { conforme as normas e a legislação. E estão, conforme a opinião das } \\
\text { pessoas de fora, ninguém apresentou discordância nesse sentido." }\end{array}$ \\
\hline $\begin{array}{c}\text { AÇÕES E } \\
\text { PROGRAMAS }\end{array}$ & VARIÁVEIS & PERCEPÇÃO \\
\hline DISCRIMINAÇÃO & $\begin{array}{l}\text { Igualdade de } \\
\text { condições salariais, } \\
\text { independentemente do } \\
\text { sexo }\end{array}$ & $\begin{array}{l}\text { "Sim, os salários são igualitários e existe o cuidado de manter os } \\
\text { relacionamentos com todos os envolvidos, respeitando suas } \\
\text { individualidades. E procuramos trocar experiências, queremos ter } \\
\text { um papel importante tanto no mercado quanto aqui dentro". }\end{array}$ \\
\hline
\end{tabular}

Quadro 7: Resultados das dimensões do modelo tridimensional - Diretor

Fonte: Elaboração própria a partir dos dados da pesquisa.

Houve grande concordância do diretor com as variáveis pesquisadas na dimensão categorias. Ressalva-se apenas que, na categoria discricionária, sua opinião é de que a necessidade de interação com a comunidade existe, sendo um problema recorrente porque o foco de atenção ou atuação social da empresa são os funcionários. Como também as ações sociais da empresa Têxtil não podem ser consideradas ações discricionárias uma vez que a organização necessita de maior planejamento, desenvolvimento e orientação para projetos mais abrangentes e próprios, inclusive para obter certificações como a ISO 26000. Assim, maior concordância do diretor foi com a categoria legal.

$\mathrm{Na}$ dimensão comportamentos e respostas, o diretor entende que as ações não objetivam mitigar impactos, o que inviabiliza a caracterização pelos comportamentos reativo e defensivo; como também os projetos não são motivados pelo desejo de antecipar-se aos problemas, não caracterizando pró-atividade. Observa que elas estão propensas à adequação das opiniões e perspectivas dos agentes externos, estando em conformidade com a resposta acomodativa.

$\mathrm{Na}$ dimensão ações e programas, os procedimentos que caracterizam a ação consumo foram evidenciados pelo diretor como eficientes. No entanto, dada as características do produto e logística da empresa, não é necessária uma atuação mais direta nesse sentido.

Apesar de uma estrutura já consolidada, no que se refere à reutilização de insumos da produção e não degradação e poluição ao ambiente, as variáveis referentes às iniciativas relacionadas a estudos de impacto ambiental e a existência de certificação ambiental não foram concordadas. Em relação à discriminação, as atitudes tomadas pela administração são percebidas pelo gerente como oportunas, do ponto de vista do impedimento de condutas que levem à discriminação no âmbito da empresa. Na segurança do produto e segurança do trabalho, o gerente verificou as variáveis como existentes. No entanto, reiterou que algumas questões precisam melhorar, como a variável ocorrência de acidentes no trabalho.

Apesar da concordância com as ações e programas apresentados, o diretor enfocou, em consonância com os outros funcionários pesquisados, que o centro de atuação social está mais voltado à satisfação das necessidades dos funcionários. Assim sua percepção é de que a Têxtil é legal, acomodativa, com foco social nos funcionários. 
Verificou-se que a opinião do gerente é mais favorável à organização que as opiniões dos funcionários. É válida a observação de constatações de agentes externos à empresa, que possuem conhecimentos e informações também distintas e obtidas de outras fontes.

\subsection{Fornecedores}

Entre os três fornecedores pesquisados, destacam-se no Quadro 8 as opiniões obtidas das variáveis pesquisadas:

\begin{tabular}{|c|c|c|}
\hline CATEGORIAS & VARIÁVEIS & PERCEPÇÃO \\
\hline DISCRICIONÁRIA & $\begin{array}{l}\text { Desenvolvimento de } \\
\text { iniciativas sociais em } \\
\text { benefício da comunidade } \\
\text { local }\end{array}$ & $\begin{array}{l}\text { "Não conheço bem todas as iniciativas desenvolvidas. Mas } \\
\text { acredito que não são muitas voluntárias, pois a gente nem tem } \\
\text { conhecimento. Não existe o hábito das empresas de adotar } \\
\text { uma postura de responsabilidade social, muitos nem sabem o } \\
\text { que é isso, nem as pessoas valorizam o que pode ser feito. } \\
\text { Acho que essas coisas dificultam quando alguém decide, } \\
\text { assim, ser socialmente responsável. Para isso, precisa de apoio } \\
\text { interno e externo à fábrica". }\end{array}$ \\
\hline DISCRICIONÁRIA & $\begin{array}{l}\text { Participação em } \\
\text { organizações cívicas ou } \\
\text { consideração de } \\
\text { problemas sociais da } \\
\text { comunidade }\end{array}$ & $\begin{array}{c}\text { "[...] muitas das atitudes são tomadas em beneficio dos } \\
\text { funcionários. Inclusive como forma de compensar a grande } \\
\text { carga de trabalho, a jornada é alta. Assim, as áreas de lazer e } \\
\text { os serviços são necessidades da empresa, já que pode existir a } \\
\text { questão da insatisfação no trabalho". }\end{array}$ \\
\hline RESPOSTAS & VARIÁVEIS & PERCEPÇÃO \\
\hline REATIVA & $\begin{array}{l}\text { Fomento de ações sociais } \\
\text { depois de protesto ou } \\
\text { reivindicações da } \\
\text { sociedade }\end{array}$ & $\begin{array}{c}\text { "A sociedade não interfere muito nesse sentido de cobrar. } \\
\text { Mas os projetos abrangem, na medida do possível. Acredito } \\
\text { que o que é feito depende da possibilidade da empresa de } \\
\text { realizar, e, talvez, das necessidades". }\end{array}$ \\
\hline DEFENSIVA & $\begin{array}{l}\text { Desenvolvimento de ações } \\
\text { ou programas sociais no } \\
\text { intuito de evitar problemas }\end{array}$ & $\begin{array}{l}\text { "Não acredito que ela tem enfrentado problemas ou alguma } \\
\text { coisa que precisasse de uma ação social imediata". }\end{array}$ \\
\hline $\begin{array}{c}\text { AÇÕES E } \\
\text { PROGRAMAS }\end{array}$ & VARIÁVEIS & PERCEPÇÃO \\
\hline MEIO AMBIENTE & $\begin{array}{l}\text { Disposição adequada de } \\
\text { resíduos sólidos e gases } \\
\text { poluentes/ } \\
\text { Desenvolvimento de } \\
\text { projetos voltados à } \\
\text { preservação do meio } \\
\text { ambiente } \\
\end{array}$ & $\begin{array}{c}\text { "Ela [a empresa] cuida dos resíduos dela, acredito que não há } \\
\text { projetos para preservação. Talvez, conforme você diz, esse } \\
\text { não seja o foco. Mas para fazer alguma coisa nesse sentido } \\
\text { tem que haver incentivos, parcerias e pesquisa e acredito que } \\
\text { a [Têxtil] ainda não esteja com planos desse tipo. Ela está } \\
\text { mais para cuidar dos resíduos gerados, e nesse ponto está tudo } \\
\text { em conformidade". }\end{array}$ \\
\hline $\begin{array}{l}\text { SEGURANÇA DO } \\
\text { PRODUTO }\end{array}$ & $\begin{array}{l}\text { Implantação de meios que } \\
\text { busquem a excelência do } \\
\text { padrão de qualidade }\end{array}$ & $\begin{array}{l}\text { "Se o foco social é segurança do produto eu acho que pode } \\
\text { ser. Porque eles são de qualidade. E acho que a empresa } \\
\text { mesmo oferece aos seus funcionários boas condições pra esse } \\
\text { trabalho. As pressões da concorrência são grandes". }\end{array}$ \\
\hline
\end{tabular}

Quadro 8: Resultados das dimensões do modelo tridimensional - Fornecedores

Fonte: Elaboração própria a partir dos dados da pesquisa

Os fornecedores pesquisados não conhecem com intensidade os projetos realizados. Acreditam que é natural que a organização seja vista como eficiente, do ponto de vista econômico, dado seu porte e suas características de mercado. A categoria ética obteve opiniões menos positivas, já que, apesar de concordarem que existe respeito à integridade física e moral de funcionários e clientes, eles não sabem da existência de código de ética.

Também como pode ser observado no Quadro 8, para um dos fornecedores pesquisados, os projetos discricionários estão relacionados à necessidade que há do fomento de ações 
discricionárias, dada as próprias características do trabalho na empresa. Assim, acreditam que, em relação às categorias de responsabilidade social, a Têxtil está mais propensa à obrigação ou responsabilidade legal.

Em relação à dimensão comportamentos e respostas, os entrevistados acreditam que conflitos externos não existem, uma vez que os tipos de relacionamento com os agentes externos à empresa não condizem com tal acontecimento. Dessa forma não há a necessidade da existência de um comportamento reativo ou defensivo por parte dela.

Em relação ao comportamento acomodativo, os pesquisados acreditam que o tipo de respostas da Têxtil está em conformidade com a opinião do público externo, e até por isso esse público não tem tanta participação em relação às práticas da organização.

Os respondentes não se mostraram propensos a uma opinião positiva em relação ao comportamento pró-ativo. Seu conhecimento sobre as ações aplicadas no âmbito interno à empresa não é grande. Assim, as pessoas ficam, por vezes, aptas a falar mais do projeto educacional e acabam não verificando alguns outros projetos realizados em parceria.

$\mathrm{Na}$ dimensão ações e programas, os fornecedores pesquisados não mostraram grande conhecimento sobre sua aplicabilidade na empresa. Acreditam que ações relacionadas ao consumo, discriminação e segurança do trabalho sejam trabalhadas eficientemente.

Em relação ao meio ambiente eles afirmaram não ter conhecimento de a empresa desenvolver projetos na comunidade para preservação ambiental e dispor informações desse tipo e reiteram a opinião de que os resíduos gerados pela produção são bem administrados.

Com base na análise das ações e programas é possível inferir que os principais argumentos favoráveis sobre o foco de atuação da Têxtil estiveram em torno da segurança do produto. Os fornecedores acreditam que produtos seguros e de qualidade fazem parte da missão e dos objetivos organizacionais, e que a empresa trabalha no intuito de proporcionar aos seus funcionários as condições necessárias para tal fim.

\subsection{Percepção dos Parceiros}

A relação de parceria para projetos sociais da empresa pesquisada é mantida apenas com esse parceiro entrevistado. Seu conhecimento é grande em relação às ações que a empresa realiza. $\mathrm{O}$ Quadro 9 aborda as principais percepções a partir do diagnóstico realizado.

\begin{tabular}{|c|c|c|}
\hline CATEGORIAS & VARIÁVEIS & PERCEPÇÕ̃ES \\
\hline LEGAL & $\begin{array}{l}\text { Cumprimento integral } \\
\text { das leis do trabalho e } \\
\text { obrigações contratuais }\end{array}$ & $\begin{array}{l}\text { "Acho que os projetos não são todos feitos por exigências legais. O } \\
\text { projeto educacional, o culinário, por exemplo, não é por exigência } \\
\text { legal. Mas é necessário estar de acordo com o que a legislação } \\
\text { determina, e isso é totalmente de acordo". }\end{array}$ \\
\hline $\begin{array}{l}\text { DISCRICIONÁR } \\
\text { IA }\end{array}$ & $\begin{array}{l}\text { Participação em } \\
\text { organizações cívicas ou } \\
\text { consideração de } \\
\text { problemas sociais da } \\
\text { comunidade }\end{array}$ & $\begin{array}{l}\text { "Os projetos estão ainda em fase inicial, a empresa está } \\
\text { desenvolvendo um núcleo de responsabilidade social aprimorado. } \\
\text { Mas conheço o projeto educacional, não é totalmente por iniciativa } \\
\text { própria, mas requer grandes recursos por parte da empresa. É um } \\
\text { projeto que muda a vida do adolescente, dá um encaminhamento para } \\
\text { o mercado de trabalho porque é um trabalho especializado. É claro } \\
\text { que precisa ainda de ajustes porque muitos ainda não sabem o que } \\
\text { fazer depois que terminam". }\end{array}$ \\
\hline RESPOSTAS & VARIÁVEIS & PERCEPÇÕES \\
\hline $\begin{array}{c}\text { ACOMODATIV } \\
\text { A }\end{array}$ & $\begin{array}{l}\text { Atuação social tendo } \\
\text { em vista o que a } \\
\text { empresa necessita e o } \\
\text { governo solicita }\end{array}$ & $\begin{array}{l}\text { "A maior parte da comunidade não requer ações sociais. Não existe } \\
\text { uma valorização ou mesmo uma visão positiva da empresa. Acredito } \\
\text { que a interferência do governo é pequena, mas tudo aquilo que é } \\
\text { requisitado é feito por ela, inclusive nosso trabalho abrange esse } \\
\text { aspecto". }\end{array}$ \\
\hline PRÓ-ATIVA & $\begin{array}{l}\text { Institucionalização de } \\
\text { projetos educacionais, } \\
\text { culturais, éticos, } \\
\text { internamente ou na }\end{array}$ & $\begin{array}{l}\text { "A nossa missão é ter a iniciativa de mostrar a responsabilidade } \\
\text { social e o que a empresa pode fazer em benefício dos atores sociais. } \\
\text { Eu conheço sim os projetos que a empresa faz. [...] A maioria das } \\
\text { ações fomos nós que buscamos, mas a empresa é muito receptiva e }\end{array}$ \\
\hline
\end{tabular}




\begin{tabular}{|c|c|c|}
\hline & comunidade local & interessada". \\
\hline $\begin{array}{c}\text { AÇÕES E } \\
\text { PROGRAMAS }\end{array}$ & VARIÁVEIS & PERCEPÇÕES \\
\hline $\begin{array}{c}\text { MEIO } \\
\text { AMBIENTE }\end{array}$ & $\begin{array}{c}\text { Disposição de } \\
\text { informações sobre } \\
\text { educação ou } \\
\text { consciência ambiental } \\
\text { no âmbito externo/ } \\
\text { desenvolvimento de } \\
\text { projetos voltados à } \\
\text { preservação do meio } \\
\text { ambiente } \\
\end{array}$ & $\begin{array}{l}\text { "Algumas palestras educativas sobre meio ambiente são feitas, mas } \\
\text { tudo dentro da empresa. Não tenho conhecimento sobre projetos } \\
\text { ambientais mais amplos, acho que não há. O meio ambiente poderia } \\
\text { ser um foco de trabalho social e bem interessante de trabalhar". }\end{array}$ \\
\hline $\begin{array}{c}\text { MEIO } \\
\text { AMBIENTE }\end{array}$ & $\begin{array}{l}\text { Tratamento e } \\
\text { reutilização de água } \\
\text { proveniente da } \\
\text { produção }\end{array}$ & $\begin{array}{l}\text { "Sei que tem reutilização de água. E acho que pela empresa trabalhar } \\
\text { com algodão, poderia ter alguma coisa relacionada ao } \\
\text { reflorestamento, mas eu não sei se, de fato, existe, acredito que não". }\end{array}$ \\
\hline $\begin{array}{l}\text { SEGURANÇA } \\
\text { DO PRODUTO }\end{array}$ & $\begin{array}{l}\text { Implantação de meios } \\
\text { que busquem a } \\
\text { excelência do padrão } \\
\text { de qualidade do } \\
\text { produto }\end{array}$ & $\begin{array}{l}\text { "O foco é a qualificação do funcionário. Pela empresa ter uma visão } \\
\text { de mercado, uma visão à frente, ela busca alternativas diversificadas } \\
\text { para a realização do trabalho e satisfação dos funcionários. A } \\
\text { empresa recebeu agora o nosso prêmio anual de qualidade no } \\
\text { trabalho, ela está dentro do processo e da busca de qualificação } \\
\text { frequente". }\end{array}$ \\
\hline
\end{tabular}

Quadro 9: Resultados das dimensões do modelo tridimensional - Parceiros Fonte: Elaboração própria a partir dos dados da pesquisa.

Conforme pode ser observado na tabela, os parceiros acreditam que os projetos sociais não são motivados apenas pela busca da adequação aos requisitos legais. Opinião essa contrária a de outros stakeholders como os funcionários. Uma vez que há grande parceria para ações sociais em benefício dos funcionários, os próprios parceiros verificam a categoria discricionária com grande aceitação. Observa-se que, apesar de eles não pontuarem a existência de projetos ambientais na comunidade, ações para melhoria da qualidade de vida os remetem ao projeto educacional, e sobre ele todos falam com grande propriedade. Para os parceiros, o caráter ético é menos característico dos projetos da Têxtil do que o discricionário.

$\mathrm{Na}$ dimensão comportamentos e respostas, os parceiros acham que reagir a problemas ou se posicionar ante a um conflito não é a característica da Têxtil, conforme opiniões dos stakeholders já pesquisados. Para os parceiros, o nível de escolaridade das pessoas da comunidade não é alto, e necessita haver uma sensibilização sobre o que é responsabilidade social e sobre o que uma organização pode impactar ou influenciar uma comunidade local. Por isso não há cobrança ou interação com essa comunidade.

O comportamento acomodativo é válido porque, apesar da pouca participação dos agentes externos, as mínimas condições por eles requeridas são consideradas e garantidas tanto em parceria quanto pela própria empresa. O caráter pró-ativo foi especificado como existente ainda que não haja maior iniciativa própria. Como também os projetos próprios são brevemente conhecidos.

Para a maior parte dos entrevistados existe um posicionamento de resposta social pró-ativo, dada a receptividade da empresa Têxtil de discutir e abordar o que melhor pode ser realizado no seu âmbito interno.

$\mathrm{Na}$ dimensão ações e programas, os parceiros revelaram a falta de conhecimento em relação às variáveis da ação consumo. Atividades ligadas ao meio ambiente, no que concerne ao trabalho com agentes externos, não foram vistas com frequência. Um parceiro levantou a questão de que a Têxtil poderia trabalhar com um projeto voltado ao reflorestamento, uma vez que produz a partir do algodão. E esse foco poderia ser considerado, já que há um eficiente trabalho com os resíduos da produção. 
Para os parceiros, algumas ações para evitar a discriminação são realizadas como semanas educativas e palestras, mas não com caráter abrangente. Em relação à segurança do produto, eles concordaram com as variáveis de pesquisa. Houve também grande concordância de que a segurança do trabalho existe na empresa, bem como foi evidenciado o caráter legal dessa atuação.

Para os parceiros, a empresa disponibiliza adequada estrutura, do ponto de vista da segurança do trabalho, no entanto este é um fator que se soma ao foco central que é o bem-estar dos funcionários. Assim sendo, para eles, a Têxtil é discricionária, pró-ativa e com atuação para os funcionários. Este é, até esse momento, o entendimento mais diverso ou conflitante sobre as ações sociais da Têxtil, ante as percepções apresentadas até então.

\subsection{Percepções dos Clientes}

Os clientes mostraram menos familiaridade e conhecimento das ações e projetos sociais da Têxtil em comparação com outros stakeholders, como mostram as respostas do Quadro 10.

\begin{tabular}{|c|c|c|}
\hline CATEGORIAS & VARIÁVEIS & PERCEPÇÕES \\
\hline LEGAL & $\begin{array}{l}\text { Efetividade no } \\
\text { pagamento de impostos e } \\
\text { tributos municipal, } \\
\text { estadual e federal }\end{array}$ & $\begin{array}{l}\text { "[...] acho que as ações de responsabilidade social têm que ser } \\
\text { fundamentadas no aspecto legal. Acredito que existe interesse } \\
\text { nos que trabalham na empresa, sobre que eles precisam, do povo } \\
\text { de fora, de como eles acham que é a postura da empresa, e tudo } \\
\text { isso contribui pra você optar por um determinado projeto [social] } \\
\text { e outro não". }\end{array}$ \\
\hline RESPOSTAS & VARIÁVEIS & PERCEPÇÕES \\
\hline REATIVO & $\begin{array}{l}\text { Ações sociais para } \\
\text { viabilizar a mitigação de } \\
\text { impactos negativos } \\
\text { provocados pela empresa }\end{array}$ & $\begin{array}{l}\text { "Não acredito que existem muitos conflitos que levem a empresa } \\
\text { a adotar essa conduta. Acho que os problemas são minimizados } \\
\text { logo que acontecem, sem que antes eles se tornem uma ameaça". }\end{array}$ \\
\hline $\begin{array}{c}\text { AÇÕES E } \\
\text { PROGRAMAS }\end{array}$ & VARIÁVEIS & PERCEPÇÕES \\
\hline CONSUMO & $\begin{array}{c}\text { Disposição de } \\
\text { informações técnicas } \\
\text { adequadas e necessárias/ } \\
\text { Modificação e/ou retirada } \\
\text { de produtos após sua } \\
\text { distribuição quando não } \\
\text { adequados à clientes ou } \\
\text { consumidores }\end{array}$ & $\begin{array}{l}\text { "O atendimento pós-venda nos deixa à vontade pra fazer qualquer } \\
\text { posicionamento da gente, opinião sabe. Muitas vezes alguns } \\
\text { produtos têm que ser retirados, ou de última hora vem novas } \\
\text { diretrizes ou layout mesmo. Aí faz de novo. [...] as normas } \\
\text { técnicas são boas, o produto passa por diversas etapas até chegar a } \\
\text { nós, e em cada etapa, mesmo não sendo mais na [Têxtil], ele é } \\
\text { bem feito, adequado". }\end{array}$ \\
\hline
\end{tabular}

Quadro 10: Resultados das dimensões do modelo tridimensional - Clientes Fonte: Elaboração própria a partir dos dados da pesquisa.

Para os clientes, o desempenho econômico está favorável e adequado às características da concorrência e demanda. Os projetos de RSE são originários do contexto e das particularidades que envolvem a organização, e também envoltos pelas necessidades e exigências legais, integrantes da conduta empresarial da atualidade.

Em relação à categoria ética, os pesquisados apontam que muitos atores sociais ainda não têm a compreensão da importância desses valores como norte de atitudes empresariais. Na categoria discricionária, a variável referente à promoção de campanhas voltadas à melhoria da qualidade de vida das pessoas da região não foi concordada, dado o fato de que a abertura com a comunidade não é grande.

$\mathrm{Na}$ dimensão comportamentos e respostas, no que se refere ao comportamento reativo, os pesquisados mostraram uma percepção e entendimento quase que em total conformidade com o que acontece na realidade da organização, já que acreditam que a natureza do tipo de sistema produtivo não acarreta problemas. 
Em relação ao comportamento acomodativo, os clientes acreditam que a maior abrangência dos projetos é um objetivo da empresa, não havendo interferência (solicitação) nesse sentido de agentes internos ou externos. No entanto, apesar disso, a organização estudada está "alinhada" com a postura ou opinião desses agentes. Para eles, a iniciativa própria sobre os projetos adotados não está clara ou visível, além disso, a maioria dos projetos não são todos conhecidos, sendo apenas o projeto educacional mencionado com maior frequência.

$\mathrm{Na}$ dimensão ações e programas, para os clientes, o foco de trabalho da empresa atualmente está em propiciar os melhores produtos, de acordo com as características e necessidades da demanda, mesmo que isso implique em maiores custos, o que denota um foco no consumo.

$\mathrm{O}$ foco no meio ambiente foi desconsiderado pelos clientes pesquisados. Eles não acreditam que haja o fomento de projetos sociais com enfoque ambiental. Acreditam que a empresa determina processos e atitudes que garantem a não existência de políticas que levem à atos discriminatórios ou ações relacionadas, mas não possuem informações concretas sobre esse aspecto. A segurança do produto foi evidenciada com aceitação pelos pesquisados. E essas percepções corroboram as especificações da ação consumo, que está muito relacionada ou atrelada à segurança do produto. Produtos seguros dão subsídios para que o ato de consumir seja feito de maneira benéfica aos indivíduos. Assim, essas duas ações foram verificadas como existentes e atuantes na empresa Têxtil.

Em relação à segurança do trabalho, os clientes reiteram que possuem conhecimento um tanto restrito em relação ao âmbito da fábrica, mas explanam que dada as características e porte organizacional, é indispensável a verificação desses aspectos, principalmente no que tange a um ambiente propício e seguro para a realização das atividades.

Com isso, é possível inferir que, para os clientes, o foco de atuação social é o consumo dos produtos, sendo de responsabilidade legal e tipo de resposta acomodativa.

\subsection{Percepção dos Consumidores}

Algumas percepções dos consumidores entrevistados podem ser evidenciadas no Quadro 11.

\begin{tabular}{|c|c|c|}
\hline CATEGORIAS & VARIÁVEIS & PERCEPÇÕES \\
\hline LEGAL & $\begin{array}{l}\text { Cumprimento integral } \\
\text { das leis do trabalho e } \\
\text { obrigações contratuais }\end{array}$ & $\begin{array}{l}\text { "Não tenho conhecimento de a empresa ter atuado fora da } \\
\text { legalidade. [...] Eu acho que ela cumpre o que deve ser feito } \\
\text { nesse aspecto [...] Nada me levou a crer que a prioridade do } \\
\text { projeto educacional, por exemplo, é estar dentro da lei. Mas } \\
\text { acho sim que, do ponto de vista legal, está tudo de acordo". }\end{array}$ \\
\hline DISCRICIONÁRIO & $\begin{array}{l}\text { Participação em } \\
\text { organizações cívicas ou } \\
\text { consideração de } \\
\text { problemas sociais da } \\
\text { comunidade }\end{array}$ & $\begin{array}{l}\text { "Sei que a empresa faz projetos sociais, e acredito que alguns } \\
\text { deles são por iniciativa própria. Ela faz também doações, mas } \\
\text { não sei a frequência. Acredito que assumir uma postura de } \\
\text { responsabilidade social não é da noite para o dia, e que a } \\
\text { empresa vem tentando trabalhar com isso, na medida do } \\
\text { possível". }\end{array}$ \\
\hline RESPOSTAS & VARIÁVEIS & PERCEPÇÕESS \\
\hline DEFENSIVO & $\begin{array}{l}\text { Desenvolvimento de } \\
\text { ações ou programas } \\
\text { sociais no intuito de } \\
\text { evitar problemas }\end{array}$ & $\begin{array}{l}\text { "Eu não acho que uma reclamação pode ser suficiente pra } \\
\text { provocar o acontecimento de uma ação social. E isso não } \\
\text { acontece com a [Têxtil] porque ela nem deve sofrer } \\
\text { reclamações ou conflitos vindos aqui de fora". }\end{array}$ \\
\hline ACOMODATIVO & $\begin{array}{l}\text { Atuação social tendo em } \\
\text { vista o que a empresa } \\
\text { necessita e o governo } \\
\text { solicita }\end{array}$ & $\begin{array}{l}\text { "Não sei se os projetos são muito abrangentes, ou se eles } \\
\text { envolvem as pessoas de fora, porque, pelo menos, para mim } \\
\text { isso não está claro. Acredito que essa informação não é muito } \\
\text { divulgada. No entanto, a sociedade não cobra e não se } \\
\text { posiciona sobre isso. O governo também não". }\end{array}$ \\
\hline PRÓ-ATIVO & $\begin{array}{l}\text { Atuação social como } \\
\text { forma de antecipar-se } \\
\text { aos problemas }\end{array}$ & $\begin{array}{l}\text { "Acho que o foco não é para antecipar-se aos problemas, só se } \\
\text { eles forem em grande quantidade, mas nunca ouvi falar que a } \\
\text { [Têxtil] enfrenta grandes conflitos ou questões problemáticas". }\end{array}$ \\
\hline
\end{tabular}

Revista de Gestão Social e Ambiental - RGSA, São Paulo, v.5, n.1, p. 85-108, jan./abr., 2011. 
Identificação das percepções de responsabilidade social empresarial: um estudo qualitativo a partir da aplicação do modelo conceitual tridimensional de performance social

\begin{tabular}{|c|c|c|}
\hline $\begin{array}{c}\text { AÇÕES E } \\
\text { PROGRAMAS }\end{array}$ & VARIÁVEIS & PERCEPÇÕES \\
\hline DISCRIMINAÇÃO & $\begin{array}{c}\text { Trabalho para mitigação } \\
\text { de discriminação social } \\
\text { ou racial entre } \\
\text { funcionários ou outros } \\
\text { relacionados à empresa }\end{array}$ & $\begin{array}{c}\text { "Acho que a discriminação mesmo é uma coisa muito forte e } \\
\text { até ruim pra empresa, e ela deve fazer de tudo pra que isso não } \\
\text { aconteça. Não ouvi falar que isso aconteceu, e se acontece } \\
\text { mesmo acho que só quem fica sabendo mesmo é o pessoal de } \\
\text { dentro. O foco social? Pode ser sim a discriminação, mas não } \\
\text { sei te dizer com certeza”. }\end{array}$ \\
\hline \multicolumn{3}{|c|}{ Quadro 11: Resultados das dimensões do modelo tridimensional - Consumidores } \\
Fonte: Elaboração própria a partir dos dados da pesquisa.
\end{tabular}

$\mathrm{Na}$ dimensão categorias, em relação à categoria econômica, todos os consumidores pontuaram que os produtos estão de acordo com sua preferência, fazendo a devida ressalva de que roupas e artigos para cama e banho estão sujeitos muito mais às escolhas pelo gosto (estilo) do comprador, do que por características intrínsecas do produto. A adequação ao poder de compra também foi concordada.

Entre eles não há conhecimento de que a empresa atuou fora da legalidade, no entanto, acreditam que o interesse pela promoção de iniciativas sociais não parte unicamente pela intenção prioritária de estar em conformidade com requisitos legais.

A categoria ética não obteve respostas firmes. Alguns consumidores especificam que essas informações são melhor dispostas no âmbito interno à organização, mas que esse conhecimento poderia ser melhor disponibilizado à eles.

Para os consumidores, o caráter discricionário existe na empresa, no entanto, não se trata ainda da característica central da organização. E assim, pela presente análise, fica a categoria econômica como a que melhor explana, na opinião dos investigados, a característica principal das categorias de RSE da Têxtil.

$\mathrm{Na}$ dimensão comportamentos e respostas, novamente os comportamentos reativo e defensivo foram menos considerados como aplicáveis na empresa, em consonância com a compreensão dos stakeholders já analisados.

O comportamento acomodativo foi melhor colocado como o tipo de responsividade da organização. Para os consumidores, a empresa procura dispor práticas e iniciativas que satisfaçam o público interno. Quanto ao alinhamento às exigências do governo ou da opinião pública, acreditam que essa iniciativa não há, de fato, por características da comunidade e do governo, que não demonstram exigências ou interesse necessários para tal.

Sobre o comportamento pró-ativo, os consumidores não conhecem a maioria dos projetos próprios ou mesmo em parceria. Essa lacuna é originária do próprio posicionamento da empresa de não divulgar e da comunidade de não buscar mostrar interesse.

$\mathrm{Na}$ dimensão ações e programas, os consumidores não evidenciaram o foco no meio ambiente já que não conhecem sobre a realização dessas atividades. $O$ foco no consumo também foi pouco visto, mas agora, devendo-se ao fato do pouco conhecimento sobre a disposição das normas técnicas e do atendimento pós-venda.

Em relação ao foco discriminatório, a falta de certeza dos consumidores sobre esse tipo de prioridade da empresa invalida a possibilidade de pôr a ação ou programa discriminação como característica da Têxtil. As variáveis da segurança do produto e da segurança do trabalho foram evidenciadas com concordância pelos pesquisados. Acreditam que a fabricação é eficiente e que a empresa tem garantia de qualidade, bem como a estrutura física propicia meios para tal.

Assim, a percepção dos consumidores é de que a Têxtil trabalha mais fortemente sua obrigação econômica, numa resposta acomodativa e com foco na segurança do produto.

\subsection{Percepção da Comunidade}


A comunidade pesquisada evidenciou menos conhecimento sobre a Têxtil e suas ações sociais. O Quadro 12 apresenta algumas percepções da comunidade.

\begin{tabular}{|c|c|c|}
\hline CATEGORIAS & VARIÁVEIS & PERCEPÇÕES \\
\hline ECONÔMICA & $\begin{array}{l}\text { Produção de bens e } \\
\text { provisão de serviços de } \\
\text { acordo com os requisitos } \\
\text { da demanda }\end{array}$ & $\begin{array}{l}\text { "Os produtos são muitos bons. Acredito que estão conforme os } \\
\text { requisitos da demanda sim. A empresa é famosa aqui na região por } \\
\text { fazer os melhores tecidos e vender a maioria dos tipos de roupas } \\
\text { para as grandes lojas". }\end{array}$ \\
\hline DISCRICIONÁRIA & $\begin{array}{l}\text { Desenvolvimento de } \\
\text { iniciativas sociais em } \\
\text { benefício da } \\
\text { comunidade local }\end{array}$ & $\begin{array}{l}\text { "Não sei se tem abertura pra tratar problemas daqui. Mas acho que } \\
\text { não existe esse costume sabe. Não, não tem incentivo [para } \\
\text { interação com a comunidade]. É como te falei, é falta de } \\
\text { costume". } \\
\text { "Campanhas pra melhorar a vida aqui não tem. Conheço sim o } \\
\text { [projeto educacional], mas não são eles que procuram os jovens } \\
\text { aqui pra participar, tem a ajuda de, acho que outra empresa, do } \\
\text { governo". }\end{array}$ \\
\hline RESPOSTAS & VARIÁVEIS & PERCEPÇÕES \\
\hline ACOMODATIVA & $\begin{array}{l}\text { Atuação social tendo em } \\
\text { vista o que a empresa } \\
\text { necessita e o governo } \\
\text { solicita }\end{array}$ & $\begin{array}{l}\text { "Essa é uma questão a se discutir, já que, por exemplo, o líder } \\
\text { comunitário não tem quase que nenhuma discussão com a } \\
\text { empresa. As pessoas também não [...]". }\end{array}$ \\
\hline PRÓ-ATIVA & $\begin{array}{l}\text { Institucionalização de } \\
\text { projetos educacionais, } \\
\text { culturais, éticos, } \\
\text { internamente ou na } \\
\text { comunidade local }\end{array}$ & $\begin{array}{l}\text { "Sei que eles adotam programas educativos, como o [projeto } \\
\text { educacional], e alguns a gente ouve falar que são feitos na fábrica, } \\
\text { pra os funcionários, mas não sei detalhar como eles são". }\end{array}$ \\
\hline PRÓ-ATIVA & $\begin{array}{l}\text { Desempenho de projetos } \\
\text { por iniciativa própria }\end{array}$ & $\begin{array}{l}\text { "Sim, a empresa faz projetos sociais, mas acho que eles são mais } \\
\text { pra o pessoal lá de dentro mesmo". }\end{array}$ \\
\hline $\begin{array}{c}\text { AÇÕOES E } \\
\text { PROGRAMAS }\end{array}$ & VARIÁVEIS & PERCEPÇÕES \\
\hline MEIO AMBIENTE & $\begin{array}{l}\text { Desenvolvimento de } \\
\text { projetos voltados à } \\
\text { preservação do meio } \\
\text { ambiente }\end{array}$ & $\begin{array}{l}\text { "Não existe políticas de preservação ambiental não. Ou, pelo } \\
\text { menos, não tenho conhecimento. Também nunca ouvi falar de } \\
\text { algum interesse sobre isso [...] Preservação ambiental ou } \\
\text { desenvolvimento sustentável não tem tanta valorização aqui pelas } \\
\text { empresas da região". }\end{array}$ \\
\hline $\begin{array}{l}\text { SEGURANÇA DO } \\
\text { PRODUTO }\end{array}$ & $\begin{array}{l}\text { Implantação de meios } \\
\text { que busquem a } \\
\text { excelência do padrão de } \\
\text { qualidade }\end{array}$ & $\begin{array}{l}\text { "Os produtos são sim de qualidade, tanto as roupas quanto os } \\
\text { artigos para cama e banho. Desse ponto de vista da fabricação, } \\
\text { acho que a empresa cuida para que seja bem feito, acho que ela } \\
\text { tem o cuidado". }\end{array}$ \\
\hline $\begin{array}{l}\text { SEGURANÇA DO } \\
\text { TRABALHO }\end{array}$ & $\begin{array}{l}\text { Fiscalização e } \\
\text { monitoramento da } \\
\text { utilização de } \\
\text { equipamentos de } \\
\text { proteção }\end{array}$ & $\begin{array}{l}\text { "Acho que se for pra ter responsabilidade social, a primeira coisa é } \\
\text { manter boas condições pra trabalhar. Não adianta pensar em fazer } \\
\text { coisas boas ou pra a comunidade ou pra empresa mesmo se os } \\
\text { funcionários não estão satisfeitos com o trabalho". }\end{array}$ \\
\hline
\end{tabular}

Quadro 12: Resultados das dimensões do modelo tridimensional - Comunidade Fonte: Elaboração própria a partir dos dados da pesquisa.

A categoria econômica foi avaliada pela comunidade como a principal obrigação da empresa. Essa constatação é, principalmente, originária do não conhecimento por parte dos pesquisados sobre as atividades voluntárias e de caráter ético que a Têxtil realiza, levando à percepção de que a categoria econômica é a responsabilidade principal que rege as ações e iniciativas da Têxtil. O caráter legal dessas atividades não é evidenciado com certeza. E pela análise da categoria discricionária, verificou-se que as pessoas têm conhecimento de que falta maior interação entre a empresa e comunidade, e que esse diálogo deve ser um processo recíproco.

$\mathrm{Na}$ dimensão comportamentos e respostas, a comunidade entende que a empresa não é reativa porque, da própria parte deles, não há qualquer tipo de reclamação ou requerimento. A 
resposta acomodativa não é aplicada, para a comunidade, principalmente por sua própria atuação e do governo, que não mantém uma relação estreita e consolidada com a empresa para troca de informações e ideias.

A pró-atividade é vista mais como característica do comportamento social da empresa. A comunidade pesquisada acredita que existem projetos consolidados, ainda que não saibam se a iniciativa é própria ou em parceria e a quem os projetos beneficiam.

$\mathrm{Na}$ dimensão ações e programas, as iniciativas sobre o meio ambiente não se mostraram, para a comunidade, como foco ou área de interesse da administração e nem mostrou conhecimento suficiente nas respostas sobre a discriminação e o consumo. Seria natural o conhecimento dessas informações se a empresa disponibilizasse procedimentos relacionados à transparência necessária para tal. A segurança do produto foi a melhor evidenciada. A comunidade afirma que a empresa atende às normas de excelência do seu padrão de qualidade, bem como concorda com as outras variáveis da pesquisa. Para a comunidade, a administração da organização tem a preocupação de oferecer produtos sem riscos ou com o mínimo de defeitos Esse entendimento é originário da confiança gerada pelos produtos vendidos.

Em relação à segurança do trabalho, a comunidade entrevistada revelou não ter conhecimento da ocorrência de acidentes. E a maioria acredita que a relevância social deve começar com a garantia e esforço contínuo para um adequado e seguro ambiente de trabalho.

Com isso, para a comunidade, o foco é a segurança do produto que está atrelada à responsabilidade econômica e tipo resposta pró-ativa.

A seguir tem-se um cubo geral onde é possível verificar a opinião de todos os stakeholders da Têxtil pesquisados.

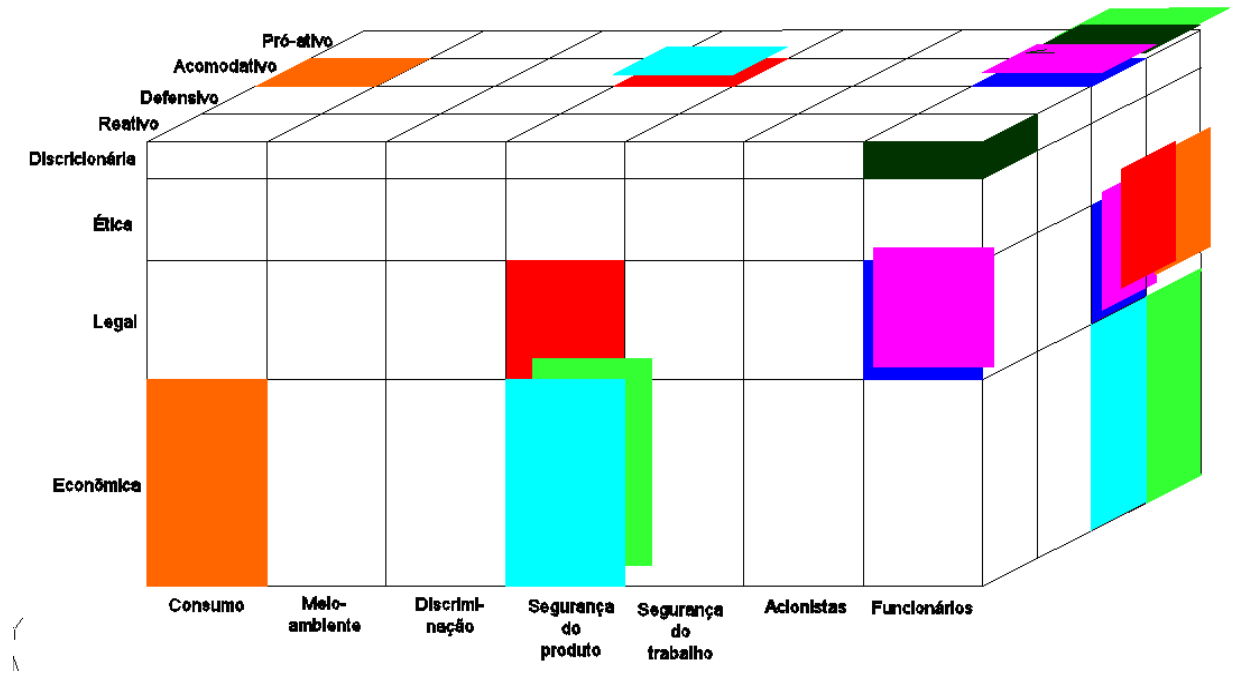

Figura 2: Cubo Tridimensional - Percepção dos Stakeholders pesquisados

Fonte: Adaptado de Carroll (1979)

Legenda:

$\square$ Parceiros

Funcionários

Clientes

Diretor

Fornecedores

Consumidores

Comunidade

Pela observação do cubo, é possível verificar que as opiniões que obtiveram maior aceitabilidade nas três dimensões do modelo, que são, respectivamente, Categorias de Performance Social, Comportamentos de Respostas e Ações e Programas foram a Legal, Acomodativa e Funcionários.

A partir dessas inferências, observa-se que as ações socialmente responsáveis da empresa pesquisada estão pautadas, segundo seus stakeholders, nos requisitos legais para empresas de seu 
porte, sendo feitas de acordo com uma possível opinião do governo e sociedade e sob foco de atuação nos funcionários.

\section{CONSIDERAÇÕES FINAIS}

Destaca-se a importância de estudar e efetivar aplicabilidades para modelos conceituais de RSE, dada a necessidade que as empresas têm de estruturar e fomentar ações sociais, e dada a necessidade de estudos dessa natureza na literatura relacionada.

Com isso, o esclarecimento de ferramentas que objetivem aumentar o campo de conhecimento e promover sua aplicabilidade à conceitos e ideias não claramente práticos apresentam devida importância. Foi nesse sentido que esse estudo procurou trabalhar, uma vez que o modelo tridimensional oferece abordagens e entendimentos, mas necessita de esclarecimentos e direcionamentos para que seja efetivado ou aplicado, dada a realidade do momento. O conhecimento sobre ações socialmente responsáveis, bem como sua aplicação obtém, com essa pesquisa, a possibilidade de maior consideração e campo de estudo, principalmente pela construção de parâmetros, instrumentos e variáveis de pesquisa para o modelo tridimensional de performance social criado em 1979.

Os resultados indicam que a percepção do público interno está relacionada à realidade da organização, com a ressalva de que ainda muitas pessoas, principalmente os voluntários, precisam de maior conhecimento sobre o que significa a atuação socialmente responsável e sobre o papel do Estado e das organizações públicas e privadas.

O conhecimento das percepções dos stakeholders de uma empresa sobre sua atuação social ajuda nesse sentido, pois evidencia quais as pessoas são mais influenciadas e suas opiniões, como também apresenta onde a empresa pode ou deve trabalhar mais para melhorar sua imagem e auferir maiores ganhos quando da participação e trabalho conjunto de membros internos e externos à ela.

Verificou-se que a percepção das pessoas está diretamente relacionada ao nível de conhecimento que elas têm sobre responsabilidade social. E conclui-se que quanto menor o conhecimento desse conceito, melhor e mais favorável é a visão sobre as iniciativas implantadas; e, em detrimento disso, quanto maior o conhecimento sobre a responsabilidade social, menor é a opinião de que os projetos da Têxtil são suficientemente abrangentes.

Conclui-se também que as pessoas não têm uma postura para mudança social da realidade em que estão situadas, esses comportamentos ocorrem tanto com pessoas da própria empresa quanto com agentes externos. Constatou-se que a RSE é pouco compreendida na comunidade local e, inclusive, por muitos atores sociais que fazem parte da realização das atividades. De fato, não existe apelo social que legitime ou requeira maiores posicionamentos sociais das empresas, e isso dificulta o investimento e o dispêndio de recursos para tal fim.

O trabalho social da Têxtil é dirigido aos stakeholders internos que são os funcionários em geral: operários e membros da administração. Esse foco acaba por desvalorizar a opinião e até o julgamento dos agentes externos, que têm participação indireta com as atividades da empresa. Assim, foi possível concluir sobre as dimensões do modelo de performance social:

$1^{a}$ Dimensão - Categorias de Responsabilidade Social: A categoria legal é a que mais se assemelha às responsabilidades da Têxtil. A categoria econômica obteve concordância significativa, já que todos os outros papéis de uma organização são derivados desse pressuposto fundamental. A categoria ética não foi considerada como característica da Têxtil por nenhum grupo de stakeholders pesquisado, pois a empresa possui muitas lacunas nessa dimensão. A categoria discricionária envolve iniciativas tidas como voluntárias, que não são totalmente conhecidas pelos stakeholders da Têxtil.

$2^{\mathrm{a}}$ Dimensão - Comportamentos e Respostas: Os resultados obtidos foram menos expressivos nessa abordagem, tendo-se verificado que os comportamentos reativo e defensivo são contrários ao tipo de resposta da Têxtil, dada às próprias características das relações entre agentes 
internos e externos da organização. O comportamento acomodativo obteve maior concordância, pois os stakeholders acreditam que a natureza legal das atividades feitas está de acordo com uma possível opinião do governo e comunidade, ainda que não sejam aparentes. A antecipação às exigências que ainda não foram feitas, que caracteriza um comportamento pró-ativo, não foi devidamente concordada.

$3^{a}$ Dimensão - Ações e Programas: Pela análise dessa dimensão, foi possível verificar que, conforme Carroll (1979) explicitou, a natureza dessas ações é diferente para cada indústria. A partir dessa constatação, verificou-se que o caráter dos projetos e benefícios fomentados pela Têxtil são, principalmente, baseados no bem-estar do funcionário, sendo este o foco social da organização. Entretanto, é válido ressaltar que alguns grupos de pesquisados têm opiniões distintas, dado o pouco conhecimento que possuem sobre a empresa.

Existe uma necessidade de que os agentes externos possam dispor de relações mais estreitas e amigáveis, para que seja feita uma correta gestão de stakeholders. Esse estudo de caso mostra que o conhecimento da percepção e entendimento dos agentes ligados à organização é importante, pois a abertura e diálogo podem beneficiar as relações com as partes interessadas.

\section{REFERÊNCIAS BIBLIOGRÁFICAS}

Atkinson, A.A., Waterhouse, J.H., Wells, R. B. (1997). A stakeholder approach to strategic performance measurement. Sloan Management Review, Spring, 25-27.

Carroll, A. B. (1979). A three-dimensional conceptual model of corporate performance. Academy of Management Review, 4 (4), 497-505.

(1999). Corporate Social Responsibility: evolution of a definitional construct. Business Society, (38) 3.

Clarkson, M. B. E. (1995). A stakeholder framework for analyzing and evaluating corporate social performance. Academy of Management Review, (20) 1, 92-117.

Donaldson, T., Preston, L. E. (1995). The stakeholder theory of the corporation: concepts, evidence and implications. Academy of Management Review, (20) 1, 65-91.

Enderle, G., Tavis, L. (1998). A Balanced Concept of the Firm and Measurement of its longterm Planning and Performance. Journal of Business Ethics, 17 (11), 1129-1144.

Friedman, M. (september 1970) The social responsibility of business is to increase its profits. New York Times Magazine.

Freeman, R. E. (1999) Divergent stakeholder theory. Academy of management review, (24)2, 233236.

Garriga, E., Melé, D. (2004). Corporate Social Responsibility Theories: Mapping the Territory. Journal of Business Ethics, 53, 51-71.

Milano, M. S.; Nunes, M. L. Kastrup, C. (2002) Responsabilidade social empresarial: o meio ambiente faz parte do negócio. Curitiba: FBPN.

Mcwilliams, A; Siegel, D. (2001). Corporate social responsibility: A theory of the firm perspective. Academy of Management Review, 26 (1), 117-127. 
Post, J. E.; Preston, L. E.; Sachs, S. (2002) Redefining the corporation: stakeholder management and organization wealth. Stanford: Stanford University Press

Quazi, A.; O'brien, D. (2000). An empirical Test of a Cross-National Model of Corporate Social Responsibility. Journal of Business Ethics, Netherlands: Kluwer Academic Publishers, 25, 33-51.

Steurer, R., Langer, M. E., Konrad, A., Martinuzzi, A. (2005). Corporations, stakeholders and sustainable development. In: A theorical exploration of business-society relations. Journal of Business Ethics, Netherlands, 61 (3), 263-281.

Wartick, S.; Cochran, P. (1985). The evolution of corporate social performance model. Academy of Management Review, 10 (4), 758-769.

Welzel, E.; Luna, M. M. M.; Bonin, M. A. S. (2008). Modelo da Dinâmica Interdisciplinar de Responsabilidade Social Corporativa: Contribuições Conceituais e Delimitação Teórica. In: ENANPAD, Anais... Rio de Janeiro, 32.

Wilson, I. (2000) The new rules of corporate conduct. Westport Connecticut: Quorum.

Wood, D. (1991). Corporate social performance revisited. Academy of Management Review, 16 (4), 691-718.

Yin, R. K. (1984). Case study research: design and methods. London: Sage.

Data do recebimento do artigo: 03/09/2010

Data do aceite de publicação: 25/03/2011 